\title{
Reduction of Xylella fastidiosa Transmission Through Pecan Scion Wood by Hot-Water Treatment
}

\author{
R. S. Sanderlin and R. A. Melanson, Louisiana State University Agricultural Center, Pecan Research-Extension \\ Station, P.O. Box 5519, Shreveport, LA 71135
}

\begin{abstract}
Sanderlin, R. S., and Melanson, R. A. 2008. Reduction of Xylella fastidiosa transmission through pecan scion wood by hot-water treatment. Plant Dis. 92:1124-1126.

Pecan (Carya illinoinensis) bacterial leaf scorch disease, caused by the bacterium Xylella fastidiosa, causes leaf loss and reduction in yield of pecans. One of the ways that the pathogen infects newly developing trees is by graft-transmission through infected scion wood. Submersion of pecan scion wood in $46^{\circ} \mathrm{C}$ water for 30 min greatly reduced transmission of $X$. fastidiosa following grafting. During a 2-year study with potted rootstock grafted to either hot-watertreated or nontreated scion wood collected from limbs of 'Cape Fear' pecan infected with $X$. fastidiosa, the pathogen was detected in $21 \%$ of the trees that developed from the nontreated scion wood and $0.7 \%$ of the trees from the hot-water-treated scions. The hot-water treatment of $46^{\circ} \mathrm{C}$ for $30 \mathrm{~min}$ did not affect graft success. Likewise, scion diameter had no effect on success of grafting or on the efficacy of hot-water treatment. Similar hot-water treatments have been efficacious in elimination of $X$. fastidiosa and some other pathogens from grapevine cuttings. The use of the hot-water treatment demonstrated in this report could be helpful to individual pecan growers and nurseries that use scion wood that may be infected with $X$. fastidiosa to reduce the occurrence of pecan bacterial leaf scorch disease in new trees.
\end{abstract}

Pecan (Carya illinoinensis (Wangenheim) K. Koch) bacterial leaf scorch (PBLS) disease, caused by Xylella fastidiosa Wells et al., can cause significant defoliation in susceptible cultivars and significantly reduce nut yields (10). PBLS is chronic; once a pecan tree is infected, the disease tends to occur every year. Visible symptoms include leaflets turning tan to reddish brown in color beginning at the tips and edges of the leaflets followed shortly with abscission of the individual affected leaflets. Bare rachises usually remain attached to terminals for a few days then also abscise. Symptoms can begin in late spring and increase in intensity through summer. As with other leaf scorch diseases of hardwood trees caused by $X$. fastidiosa, PBLS may occur on one limb of a tree or throughout the tree (5).

Over a 3-year study, the average kernel weight loss of nuts from infected terminals of severely diseased 'Cape Fear' trees was $16 \%$ (10). The crop production lifetime of pecan trees can be several decades, and cumulative loss of crop from trees that are infected early in their life may total hundreds of kilograms of yield loss.

Corresponding author: R. S. Sanderlin

E-mail: rsanderlin@agcenter.lsu.edu

Accepted for publication 26 March 2008.

doi:10.1094/PDIS-92-7-1124

(C) 2008 The American Phytopathological Society
Graft-transmission is one means that the pathogen can be introduced into orchards and may represent a primary means of infection of young trees because pecan cultivars are clonally propagated $(9,10)$. A simple method for eliminating $X$. fastidiosa from scion wood could be a useful technique to reduce the rate of introduction of the pathogen into young trees.

Hot-water treatment of infected scions has been used to eliminate $X$. fastidiosa, fungal pathogens, insects, and nematodes from grape cuttings $(1,2,4,6,7,13)$. The objective of this study was to evaluate the efficacy of hot-water treatment for elimination of $X$. fastidiosa from pecan scion wood prior to grafting. The possible effect of scion diameter on graft success and efficacy of hot-water treatment was also investigated.

\section{MATERIALS AND METHODS}

Scion wood collection and storage. In 2004, 17-year-old 'Cape Fear' pecan trees that had been identified as infected with $X$. fastidiosa by symptoms and enzymelinked immunosorbent assay (ELISA) (Agdia, Inc., Elkhart, IN) were used as sources of scion wood. To induce growth that would be suitable for scion wood, limbs on these trees were pruned at least 1 $\mathrm{m}$ from their terminals in spring 2004 and again in 2005. Scion wood was cut from these trees in January 2005 and 2006. Only limbs that had been identified with PBLS during the previous summer were cut to stimulate growth that could be used for scion wood. Scions were prepared from either 1- or 2-year-old limb growth. Limb sections without lateral bud growth were cut into approximately $15-\mathrm{cm}$ lengths. Each scion contained two or more primary or secondary lateral buds. The cut ends of the scions were sealed with a beeswax and rosin mixture to reduce dehydration. The scions were grouped into bundles of 50 pieces, wrapped in moist paper towels, and stored at 4 to $7^{\circ} \mathrm{C}$ in plastic bags until use.

Rootstocks. The rootstocks used in this test were 'Moore' seedlings purchased from a commercial nursery as bare-rooted trees with approximately 0.6 to $1 \mathrm{~m}$ of central stem growth. The rootstocks were transplanted into Metro-Mix 702 plant medium (SunGro Horticulture Distribution, Inc., Bellevue, WA) in 20.9-liter pots. Trees used in 2005 were maintained in a greenhouse; those used in 2006 were maintained outside through the duration of the test.

Hot-water treatment and grafting. Scion wood used in the test was grafted onto the rootstocks in May 2005 and 2006. The scions were grafted immediately after removal from storage or subjected to the hot-water treatment procedure then immediately used for grafting. The hot-water treatment consisted of submerging the scion wood in a water bath at $46^{\circ} \mathrm{C}$ for 30 min. Scions were submerged by bundling five pieces with a metal rod (18 g). Ten or 20 scions were treated each time. The minimum and maximum temperature variations of the water were recorded throughout each treatment period. After 30 min, the scions were removed and immediately submerged in room temperature water (about $22^{\circ} \mathrm{C}$ ) for $1 \mathrm{~min}$ to remove the heat.

The four-flap technique was used for all grafts (12). Following grafting, the trees were arranged in a completely randomized design with rootstocks grafted to nontreated and hot-water-treated scions intermixed within rows of pots. The trees used in the 2005 test were maintained in an area of $2.9 \mathrm{~m}^{2}$ and the 2006 trees in an area of $20.6 \mathrm{~m}^{2}$. The diameter of the scions used in the test was measured immediately following grafting.

PBLS and $X$. fastidiosa infection. The trees were observed for graft success and symptoms of PBLS throughout the foliation period in 2005 and 2006. When PBLS-like symptoms were found on individual trees, the trees were assayed for infection by ELISA using the rachises 
from three symptomatic leaves per tree. An absorbance at $640 \mathrm{~nm}$ at least three times greater than the absorbance of noninfected 'Cape Fear' foliage was rated as a positive reaction for $X$. fastidiosa. All trees that had not developed symptoms and assayed positive for $X$. fastidiosa during the summer were tested for infection in October by ELISA. The 2005 test trees were assayed again in October 2006, and the 2006 test trees were assayed again in October 2007.

Data analysis. $t$ tests of parameter values were used to evaluate the effects of the hot-water treatment. Correlation analysis was used to compare scion diameters for the treated and nontreated scions.

\section{RESULTS}

Hot-water treatment and grafting. The temperature of the water bath generally did not vary more than $0.5^{\circ} \mathrm{C}$ from $46^{\circ} \mathrm{C}$ during the 30 min hot-water treatment. In 2005, $62.5 \%$ of the scions subjected to the hot-water treatment prior to grafting produced successful grafts (Table $1)$. Eighty percent of the scions that were not treated produced successful grafts (Table 1). Graft success in 2006 was 92 and $87 \%$ for the hot-water-treated and nontreated scions, respectively (Table 1 ). There was no significant difference between treatments for graft success (Table 2).

There were no significant differences in the mean scion diameter used for each treatment in either year (Tables 1 and 3). Similarly, there was no correlation between scion diameter and graft success in either year (Table 3 ). In addition, there was no correlation between the diameter of the scions used in this test and the sciontransmission of the pathogen or the apparent elimination of the pathogen by hotwater treatment and scion size (Table 3 ).

PBLS and $X$. fastidiosa infection. None of the 25 trees that grew from the hot-water-treated scions in 2005 developed symptoms of PBLS, and they all tested negative for infection by $X$. fastidiosa when assayed by ELISA in both 2005 and 2006. Two of the 24 trees produced from the nontreated scions in 2005 were symptomatic. These two and one other were positive for $X$. fastidiosa infection in 2005 ; the same three trees were symptomatic and ELISA positive in 2006 (Table 1).

One of the trees that grew from the hotwater-treated scions grafted in 2006 developed PBLS and was positive for $X$. fastidiosa infection (Table 1). Another tree from a treated scion was rated as having possible symptoms but was negative in the ELISA test (Table 1). This tree did not develop symptoms in 2007 and was negative for $X$. fastidiosa in two subsequent assays. Sixteen trees from the nontreated scions were infected (Table 1).

When the 2006 test trees were assayed in October 2007, 15 of the nontreated and 17 of the hot-water-treated trees had died, apparently from maintenance neglect. Included in this group were seven of the 16 nontreated trees that were infected in 2006, and the one infected hot-water-treated tree. The remaining nine infected trees from 2006 gave a positive reaction for $X$. fastidiosa in the 2007 ELISA, and one additional nontreated tree that was negative in 2006 was positive for infection in 2007 (data not shown). Of the remaining 98 hotwater-treated trees from 2006, none assayed positive for infection.

In 2005, there was a marginal difference $(P=0.07)$ between scion wood treatment prior to grafting and the number of infected trees produced from the grafts (Table 2). No infected trees developed from the treated scions. In 2006, there was a highly significant difference $(P<0.001)$ between treatment and the number of infected trees (Table 2). Over the period of the test, $21.3 \%(19 / 89)$ of the trees from the nontreated scions were infected. A $21 \%$ graft-transmission rate would have pro- duced 29 infected trees from the 140 trees produced from the hot-water-treated scions. Only one of 140 trees $(0.7 \%)$ that developed from the hot-water-treated scions was infected. Thus, the hot water treatment had an apparent efficacy rate of nearly $97 \%$ in this test for elimination of the pathogen from scion wood.

\section{DISCUSSION}

Submerging scions in $46^{\circ} \mathrm{C}$ water for 30 min prior to grafting was effective in near complete elimination of $X$. fastidiosa from infected scion wood. During the course of the test, only one tree of the 140 trees produced from hot-water-treated scions was infected with $X$. fastidiosa. Grafting with nontreated scions resulted in infection of $21.3 \%$ of the resulting trees. The test trees were monitored for two growing seasons following grafting. There were no changes in the 2005 test trees during 2006. In 2007, only one additional nontreated 2006 tree became infected in the second year of growth, and no additional trees in the hotwater-treated group were infected. These results indicate that hot-water treatment is very effective in reducing transmission of $X$. fastidiosa through pecan scion wood.

Scion wood pieces used in this test were of typical diameter sizes used for standard pecan grafting procedures (whip, four-flap, and bark grafts). Scion diameter had no effect on graft success, the rate of grafttransmission of $X$. fastidiosa, or on the efficacy of the hot-water treatment for killing the pathogen.

Because the test trees were not isolated from insects, it is possible that the one hotwater-treated scion that produced an in-

Table 2. Treatment effects on hot-water test parameters ${ }^{a}$

\begin{tabular}{llcccc}
\hline Year & Graft success & \multicolumn{2}{c}{ PBLS symptoms } & \multicolumn{2}{c}{ Xylella fastidiosa-infected } \\
\hline \multirow{2}{*}{2005} & 0.1172 & $2005^{\mathrm{b}}$ & 2006 & 2005 & 2006 \\
\cline { 2 - 5 } & & 0.1465 & 0.0705 & 0.0705 & 0.0705 \\
2006 & 0.2256 & $2006^{\mathrm{b}}$ & 2007 & 2006 & 2007 \\
\cline { 2 - 5 } & & $<0.0001$ & $<0.0001$ & $<0.0001$ & $<0.0001$ \\
\hline
\end{tabular}

${ }^{a}$ Probability values from $t$ test comparison of trees produced from scions which received hot-water treatment and scions that were not treated. PBLS = pecan bacterial leaf scorch.

b The trees used in 2005 were monitored through 2006, and the trees used in 2006 were monitored through 2007.

Table 1. Hot-water treatment test parameters

\begin{tabular}{|c|c|c|c|c|c|c|c|c|c|c|}
\hline & \multicolumn{2}{|c|}{ No. scions used } & \multicolumn{2}{|c|}{ Graft success } & \multicolumn{2}{|c|}{ Mean scion diameter ${ }^{\mathrm{a}}$} & \multicolumn{2}{|c|}{$\begin{array}{c}\text { Trees with PBLS } \\
\text { symptoms }\end{array}$} & \multicolumn{2}{|c|}{$\begin{array}{l}\text { No. } X \text {. fastidiosa- } \\
\text { infected trees }\end{array}$} \\
\hline & 2005 & 2006 & 2005 & 2006 & 2005 & 2006 & $2005^{c}$ & $2006^{d}$ & 2005 & 2006 \\
\hline Iot- - & 40 & & 5 & & & & 0 & 2 & 0 & 1 \\
\hline Nontreated scions & 30 & 75 & 24 & $0 J$ & & 11.0 & 2 & 16 & 3 & 16 \\
\hline \multicolumn{11}{|c|}{$\begin{array}{l}\text { a Scion diameter measured in millimeters. Diameter range in } 2005 \text {, Min. }=8.0, \text { Max. }=15.3, \mathrm{SD}=1.8 \text {; in 2006, Min. }=7.4, \text { Max. }=21.6, \mathrm{SD}=2.2 . \\
\text { b Infection was determined by enzyme-linked immunosorbent assay (ELISA). } \\
\text { c The trees used in } 2005 \text { were monitored through } 2006 \text {; the infected tree that did not develop symptoms in } 2005 \text { did have symptoms in } 2006 \text {. There were no } \\
\text { other changes in the } 2005 \text { trees. } \\
\text { d The trees used in } 2006 \text { were monitored through } 2007 \text {. One additional tree in the nontreated group was recorded as infected in } 2007 \text {; no other trees in the } \\
\text { treated group became infected and the tree that had possible pecan bacterial leaf scorch (PBLS) symptoms in } 2006 \text { did not develop symptoms in } 2007 \text { and } \\
\text { assayed negative for Xylella fastidiosa. }\end{array}$} \\
\hline
\end{tabular}


Table 3. Lack of correlation of hot-water test parameters with scion diameter ${ }^{\mathrm{a}}$

\begin{tabular}{|c|c|c|c|c|c|c|c|}
\hline \multirow[t]{2}{*}{ Year } & \multirow[t]{2}{*}{ Correlation analysis } & \multirow[t]{2}{*}{ Treatment $^{b}$} & \multirow[t]{2}{*}{ Graft success } & \multicolumn{2}{|c|}{ PBLS symptoms ${ }^{\mathrm{c}}$} & \multicolumn{2}{|c|}{ Xylella fastidiosa-infected } \\
\hline & & & & $2005^{\mathrm{d}}$ & 2006 & 2005 & 2006 \\
\hline \multirow[t]{4}{*}{2005} & Correlation coefficient & 0.0589 & 0.0590 & 0.0173 & 0.1125 & 0.1125 & 0.1125 \\
\hline & $P$ value & 0.6283 & 0.6274 & 0.9062 & 0.4415 & 0.4415 & 0.4415 \\
\hline & No. comparisons & 70 & 70 & 49 & 49 & 49 & 49 \\
\hline & & & & $2006^{\mathrm{d}}$ & 2007 & 2006 & 2007 \\
\hline \multirow[t]{3}{*}{2006} & Correlation coefficient & 0.0090 & 0.0829 & 0.0347 & 0.0040 & 0.0123 & 0.0187 \\
\hline & $P$ value & 0.8997 & 0.2430 & 0.6438 & 0.9620 & 0.8699 & 0.8212 \\
\hline & No. comparisons & 200 & 200 & 180 & 148 & 180 & 148 \\
\hline
\end{tabular}

a Scion diameter was measured immediately after grafting.

b Treatments were scion wood submerged in $46^{\circ} \mathrm{C}$ water for 30 min prior to grafting or no treatment of scion wood.

c PBLS = pecan bacterial leaf scorch.

d The trees used in 2005 were monitored through 2006, and the trees used in 2006 were monitored through 2007.

fected tree could be the result of insecttransmission. Likewise, some of the infected trees in the nontreated scion group could also be the result of insecttransmission of the pathogen rather than scion-transmission. If insect-transmission occurred in this test, it appears to have been inconsequential relative to the interpretation of the results because only one of the trees from the treated scions was infected. The lack of additional infected trees in the treated group the following year suggests that no insect transmission occurred.

The rootstocks were not assayed for infection prior to grafting and the possibility of some pathogen transmission through the rootstock cannot be eliminated (11). Nonetheless, a survey of the nursery from which the rootstocks were purchased during the summer did not reveal rootstock with symptoms of PBLS (personal observation). As with the possibility of insect-transmission, any rootstock-transmission that occurred in this test must have been low because only one infected tree developed in the hot-water-treated scion group. In addition, none of the seedlings that grew from the failed grafts developed PBLS symptoms. ELISA screening of some of the rootstocks that grew following failed grafts did not detect any infected rootstocks.

For this study, only one temperature and exposure time was tested. This regime was chosen based on the positive results obtained with elimination of the Pierce's disease pathogen from grape cuttings (4). It may be that other temperature and time regimes would work as well for the elimination of the bacterium. However, the combination of $46^{\circ} \mathrm{C}$ for $30 \mathrm{~min}$ did not cause detectable harm to the scion wood and did not affect the success rate of the graft attempts.

A preliminary evaluation of the response of scion wood exposed to higher water temperatures for $30 \mathrm{~min}$ was evaluated visually. Scion wood of four cultivars (Cape Fear, Desirable, Schley, and Pointe Coupee) was treated at 46,50 , and $52^{\circ} \mathrm{C}$. Heat damage was determined from longi- tudinal cuts made beneath the outer bark up to $72 \mathrm{~h}$ after treatment. There were visible differences in sensitivity to hot water among the cultivars used in this test. None of the cultivars showed visible damage to the wood or cambium when submerged at $46^{\circ} \mathrm{C}$ for $30 \mathrm{~min}$. Only minimal damage was observed on one cultivar after treatment at $50^{\circ} \mathrm{C}$, but damage was common in three of the four cultivars when treated at $52^{\circ} \mathrm{C}$. The scions used in these temperature exposures were not grafted to rootstocks, but it is assumed that the use of scion wood with visible discoloration to the cambium would reduce the graft success rate. Thus the use of $46^{\circ} \mathrm{C}$ allows for a margin of error in temperature overrun without damaging the scion wood.

Heat shock treatment of dormant grape cuttings has been shown to increase the heat tolerance of the cuttings during heat therapy (8). If dormant pecan scion wood responds in the same way to heat shock treatment, it may be possible to use a higher temperature to eradicate $X$. fastidiosa from scion wood without damage to the woody tissue.

Because of the simplicity and high level of effectiveness of the hot-water treatment procedure tested in this study for reduction of the pathogen in pecan scion wood, this technique could be very useful for growers who collect their own scion wood. It could also be a useful method for commercial nurseries whose only source of scion wood for certain cultivars is from $X$. fastidiosainfected trees.

Heat therapy using hot water has long been recognized as a practical and effective means of freeing infected grape (Vitis vinifera) cuttings of $X$. fastidiosa (4), and is sometimes recommended as a means to reduce the probability of introducing exotic strains of the pathogen through grapevine movement (3). However, hot-water treatment apparently has not been tested with other hosts of X. fastidiosa as a potential management tool. The work reported here using pecan scion wood appears to be the first demonstration of using hot water to reduce $X$. fastidiosa transmission from a host other than grape. The use of this tech- nique may prove efficacious in some other commercial hardwood hosts of $X$. fastidiosa, such as almonds, walnuts, peaches, and plums, that can be propagated by grafting.

\section{LITERATURE CITED}

1. Burr, T. J., Ophel, K., Katz, B. H., and Kerr, A. 1989. Effect of hot water treatment on systemic Agrobacterium tumefaciens biovar 3 in dormant grape cuttings. Plant Dis. 73:242245.

2. Fourie, P. H., and Halleen, F. 2004. Proactive control of Petri disease of grapevine through treatment of propagation material. Plant Dis. 88:1241-1245.

3. Frison, E. A., and Ikin, R., eds. 1991. FAQ/IBPGR Technical guidelines for the safe movement of grapevine germplasm. Food and Agriculture Organization of the United Nations. Rome/International Board for Plant Genetic Resources. Rome, Italy.

4. Goheen, A. C., Nyland, G., and Lowe, S. K. 1973. Association of a rickettsialike organism with Pierce's disease of grapevine and alfalfa dwarf and heat therapy of the disease in grapevines. Phytopathology 63:341-345.

5. Gould, A. B., and Lashomb, J. H. 2005. Bacterial leaf scorch of shade trees. American Phytopathological Society, St. Paul, MN. http:// www.apsnet.org/online/feature/bls.

6. Haviland, D. R., Bentley, W. J., and Daane, K. M. 2005. Hot-water treatments for control of Planococcus ficus (Homoptera: Pseudococcidae) on dormant grape cuttings. J. Econ. Entomol. 98:1109-1115.

7. Lear, B., and Lider, L. A. 1959. Eradication of root-knot nematodes from grapevine rootings by hot water. Plant Dis. Rep. 43:314-317.

8. Morrell, A. M., and Wample, R. L. 1995. Thermotolerance of dormant and actively growing Cabernet Sauvignon is improved by heat shock. Am. J. Enol. Vitic. 46:243-249.

9. Sanderlin, R. S. 2005. Cultivar and seedling susceptibility to pecan bacterial leaf scorch caused by Xylella fastidiosa and graft transmission of the pathogen. Plant Dis. 89:446449.

10. Sanderlin, R. S., and Heyderich-Alger, K. I. 2003. Effects of pecan bacterial leaf scorch on growth and yield components of cultivar Cape Fear. Plant Dis. 87:259-262.

11. Sanderlin, R. S., and Melanson, R. A. 2006. Transmission of Xylella fastidiosa through pecan rootstock. HortScience 41:1455-1456.

12. Vanerwegan, J. 1975. A new grafting procedure. Pecan South 2:70-71.

13. Von Broembsen, S., and Marais, P. G. 1978. Eradication of Phytophthora cinnamoni from grapevine by hot water treatment. Phytophylactica 10:25-27. 